\title{
Competencies and Learning for Management Information Systems
}

\author{
Jens Kaasbøll and Marlen Stacey Chawani \\ University of Oslo, Oslo, Norway
}

jensj@ifi.uio.no; marlene483@gmail.com

\author{
Gro Alice Hamre \\ Norwegian University of \\ Science and Technology, \\ Trondheim, Norway
}

groah@idi.ntnu.no

\author{
Jon Sandvand \\ Inmeta Consulting, Oslo, \\ Norway
}

kujonen@gmail.com

\begin{abstract}
Previous research has established that users need competence in both computing and the context of the software. Information systems often fail due to low competence amongst users, and no study is known to provide a systematic account of the user competence needed. This research concerns competence needs amongst prospective users of a computerised management information system where there is no operational computer based IS from which to obtain data. The study shows that three subject matter areas of user competence are needed for people who will use computerised IS -- knowledge on how the domain is represented, work competence, and computer literacy. Work competence is mainly practice based, while the domain related knowledge and computer literacy are based on explicit concepts, grounded in science or technology. User training should therefore start with practice in the case of work competence, while presentation of principles, concepts, and structures would constitute a better starting point when teaching computer literacy and how the domain is represented.
\end{abstract}

Keywords: Organisational learning, user competence, user training, support, computer literacy, information system adoption.

\section{Introduction}

A classical model in the organisational learning literature is based on a main distinction between

Material published as part of this publication, either on-line or in print, is copyrighted by the Informing Science Institute. Permission to make digital or paper copy of part or all of these works for personal or classroom use is granted without fee provided that the copies are not made or distributed for profit or commercial advantage AND that copies 1) bear this notice in full and 2) give the full citation on the first page. It is permissible to abstract these works so long as credit is given. To copy in all other cases or to republish or to post on a server or to redistribute to lists requires specific permission and payment of a fee. Contact0HPublisher@InformingScience.org to request redistribution permission. tacit and explicit knowledge (Nonaka, 1994). Tacit knowledge concerns skills, crafts, and know-how, and it is validated when used in work by individuals or groups. It can encompass both bodily skills and cognitive schemes (Nonaka, 1994). Explicit knowledge is represented in print or digital media, so it can be shared and discussed in conversations. Scientific knowledge falls under the explicit category. 
Further, the Nonaka (1994) model also characterises learning according to the tacit-explicit categories. Consequently, if subject matter areas of competence for information systems use can be characterised according to these categories, the model might provide insight into possible learning processes and training for supporting the learning. Therefore, this paper aims at characterising the subject matter areas of competence for users of management information systems (MIS) according to Nonaka's (1994) model. Based on empirical studies and literature, the paper will identify starting points for training in the different subject matter areas.

The research was carried out in Malawi as a part of a multi-country project on health management information systems (HMIS) in Africa and Asia (Braa, Monteiro, \& Sahay, 2004). The HMIS produces health indicators, such as immunisation coverage and malaria incidences for specified areas and periods, visualised in graphs. The indicators are used for health management at all levels in the country. The underlying data on individual cases is recorded manually in registers, and the counting of cases to produce aggregated data to enter in a computerised database is also done manually. The chief software developer made a rough estimate that $80 \%$ of resources in the multi-country project are spent on training and support.

\section{Literature Review}

Development of competence for improving information systems requires that organisational learning takes place. Nevertheless, the individual will be taken as a starting point for characterising learning.

Following Lai (1997), individual learning is development of competence that provides a relatively stable change of the potential for action. The requirement of relative stability is necessary to differentiate changes in patterns of behaviour from random changes. If action does not take place, the reason may be that there is no room for action, although the competence is present. Change of behaviour therefore also presupposes the necessary room for action.

While individual learning aims at changing individual action, organisational learning concerns development of relatively stable change of the potential for cooperation (Skorve, 2007). And again, unless conditions such as management commitment and resources are present, the organisational competence will not lead to changes in the organisational behaviour. For example, the staff might have learnt that regular meetings with neighbouring clinics are useful, but unavailability of transport renders these meetings impossible.

From the concept of cooperation follows that two is the smallest number of people who have to be involved for organisational learning to take place. Cooperation is to be understood in a broad sense, including the relation between a manager and a subordinate, regardless of the democratic or dictatorial attitude of the manager. Organisational performance is dependent on both individual and cooperative work, so change of this performance may require both individual and organisational learning.

Recalling Nonaka's (1994) model, explicit knowledge is the theoretical type of knowledge represented in textbooks and other representations that are detached from the activity where the knowledge is used and which is often called know-that. By contrast, tacit knowledge denotes the know-how, skills, and automated procedures that are used in familiar situations. Lam (2000) has developed this model further through characterising four types of knowledge, as shown in Figure 1 .

1. Embrained (individual, explicit): An individual's formal, abstract, or theoretical knowledge.

2. Encoded (collective, explicit): Knowledge with external representation, including data in computers. 
3. Embedded (collective, tacit): Shared beliefs and understanding about organisational routines and norms.

4. Embodied (individual, tacit): Practical skills and individual beliefs.

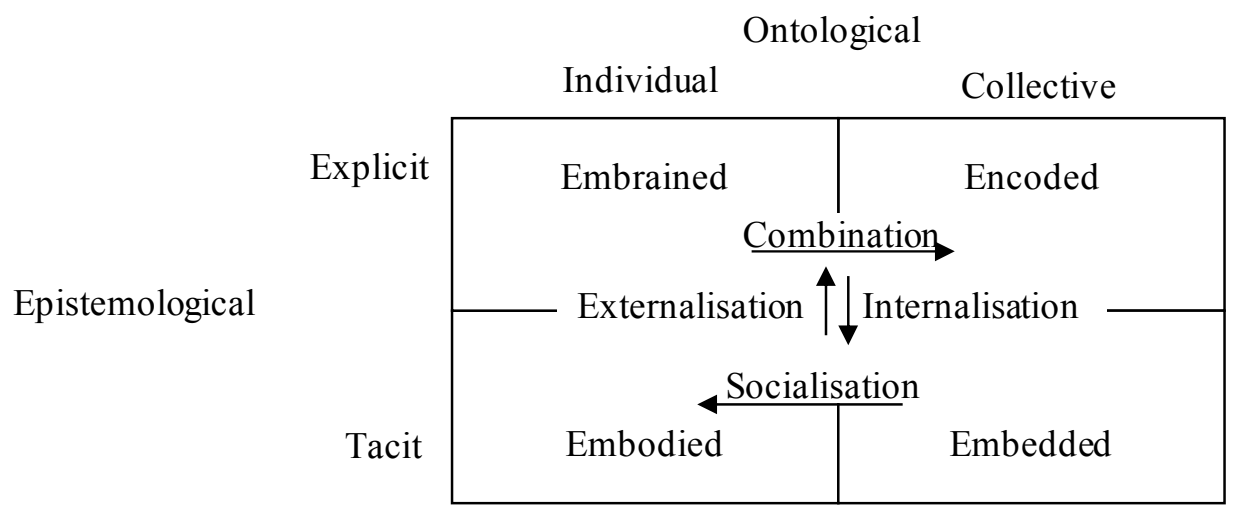

Figure 1. Knowledge types and the knowledge development process

Nonaka (1994) also identified four processes of transformation of knowledge. Starting from the embedded knowledge, individuals are socialized into a community. The social process of combining different chunks of individual knowledge is called combination. The transformation of the explicit to the tacit is called internalisation, while the opposite process is externalisation, and these could take place in both the individual and the collective case.

Mintzberg (1983) characterises organisations according to high and low standardisation of knowledge, with bureaucracies at the higher end and adhocracies at the lower. High standardisation requires explicit knowledge, while low standardisation can be supported by tacit knowledge. Further, in the machine bureaucracy, the knowledge is collective, corresponding to the encoded quadrant of Figure 2a. Lam (2000) thus argues that the professional bureaucracy, machine bureaucracy, and operating adhocracy in the sense of Mintzberg (1983) are associated with a dominant knowledge type, as illustrated in Figure 2b. None of Mintzberg's (1983) organisational types has the embedded knowledge type as its dominant type. Lam (2000) characterises the Japanese ideal organisational type to allow a non-hierarchical team structure to operate in parallel with its hierarchical management, glued together by a strong corporate culture. The latter constitutes its knowledge base, which is of the embedded type, so Lam (2000) places this organisation type, called the J-form, in the embedded knowledge quadrant of the $2 \times 2$ matrix, see Figure $2 b$.

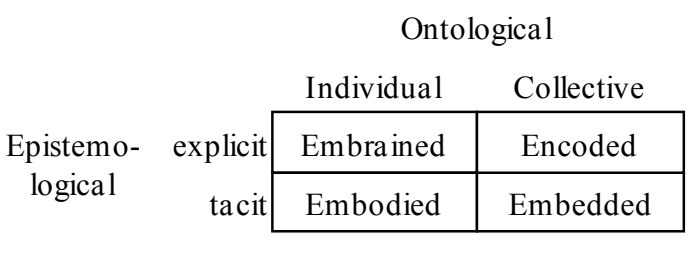

a) Knowledge types
Knowledge agent

\begin{tabular}{|c|c|c|}
\hline \multirow{3}{*}{$\begin{array}{rr}\text { Standardi- high } \\
\text { sation of } & \\
\text { knowledge } & \\
\text { and work } & \text { low }\end{array}$} & Individual & Organisation \\
\hline & $\begin{array}{l}\text { Professional } \\
\text { bureaucracy }\end{array}$ & $\begin{array}{c}\text { Machine } \\
\text { bureaucracy }\end{array}$ \\
\hline & $\begin{array}{l}\text { Operating } \\
\text { adhocracy }\end{array}$ & $\begin{array}{c}\mathrm{J} \text {-form } \\
\text { organisation }\end{array}$ \\
\hline
\end{tabular}

b) Organisational types

Figure 2. Knowledge types and corresponding organisational types. Adapted from (Lam, 2000) 
The case studied is a professional bureaucracy, and it should be dominated by the embrained knowledge of highly trained individual experts, according to (Lam, 2000). This knowledge constitutes the basis for standardisation of coordination. According to the theory, there is a limited sharing of knowledge across functional boundaries, inhibiting the transfer of tacit knowledge.

Instead of using the word knowledge, the concept competence will be used in the following to signal that the abilities of those competent are related to specific tasks.

The HMIS is used in a professional bureaucracy, but its data is explicit and collective, corresponding to the encoded type in Lam's (2000) typology. However, other studies of HMIS in the region conclude that local contextualisation of training is necessary for developing the competence needed (Mukama, 2003; Williamson, 2001), thus supporting the need for the embedded type of competence.

Concerning health management, its tools and techniques can be learnt in school. However, according to Mintzberg (2004), management competence and leadership competence, in particular, can only be developed based on experience. Due to managers' role, their experience will be part of the collective area in Lam's model; that is the embedded competence.

Orlikowski (1992) demonstrated the need for learning how a groupware system fit into work. Sein, Bostrom, and Olfman (1998) proposed a six step model for user competence, where the three lower steps concerned learning to use the functionality of the software. Step four was to understand the general purpose of the system in the organisation, step five, inferential, to develop more abstract concepts in order to see what the system could do in addition to what training said, and step six, motivational, to develop the imagination to see what the system could do to oneself and the organisation. Thus, competence on computer systems as well as on their use seems necessary.

Marcolin, Compeau, Munro, and Huff (2000) used the categorisation of cognitive, skills, and affective competence for studying methods of measuring user competence. Skills relate to the lower levels of the model of Sein and colleagues (1998), while cognitive competence concerns the higher ones. The affective competence, which Marcolin and others studied, was self-efficacy. Gupta and Bostrom (2006) added metacognitive learning outcomes to this triple, and other research supports the importance of including problem solving skills in IT competence (Phelps, Hase, \& Ellis, 2005). While these dimensions are generally applicable to all learning and therefore to any subject matter area, they do not address the specific subject matter areas of information systems.

"Knowledge domain areas" are also brought in by Marcolin et al. (2000) as a dimension in their classification of user competence, and word processors and spread sheets constitute the knowledge domain areas of their study. These knowledge domain areas concern only the type of software used, while Orlikowski (1992) and Sein et al. (1998) emphasized the need for competence both in computing and its context. In a study of ERP implementation, Coulson, Shayo, Olfman, and Rohm (2003) stressed the importance of the business procedures and developed a knowledge level model of training outcome based on the model of Sein and others (1998), see Table 1. Therefore, competence of how IT can support and interact with the tasks of the users should be a component of user competence. 
Table 1. Knowledge level outcomes for training (Coulson et al., 2003)

\begin{tabular}{|l|l|l|}
\hline KNOWLEDGE LEVEL & FOCUS & ERP SYSTEM FOCUS \\
\hline Command Based & Syntax and semantics & $\begin{array}{l}\text { Learning the nuances of the system } \\
\text { interface }\end{array}$ \\
\hline Tool Procedural & $\begin{array}{l}\text { Combining commands to } \\
\text { complete tasks }\end{array}$ & $\begin{array}{l}\text { Learning the steps to enter and recall } \\
\text { transaction data }\end{array}$ \\
\hline Business Procedural & $\begin{array}{l}\text { Application of tool procedures } \\
\text { to a task }\end{array}$ & $\begin{array}{l}\text { Learning to complete an entire busi- } \\
\text { ness process (i.e., procurement) }\end{array}$ \\
\hline Tool Conceptual & $\begin{array}{l}\text { The big picture of what to do } \\
\text { with the tool }\end{array}$ & $\begin{array}{l}\text { Understanding workflow of the whole } \\
\text { process and the organizational impacts }\end{array}$ \\
\hline Business Motivational & Reason to use & $\begin{array}{l}\text { Business purpose of the system (i.e., } \\
\text { integration, competitive necessity) }\end{array}$ \\
\hline Meta-Cognitive & Learning to learn & $\begin{array}{l}\text { Continuous learning cycle- ways to } \\
\text { approach learning the system }\end{array}$ \\
\hline
\end{tabular}
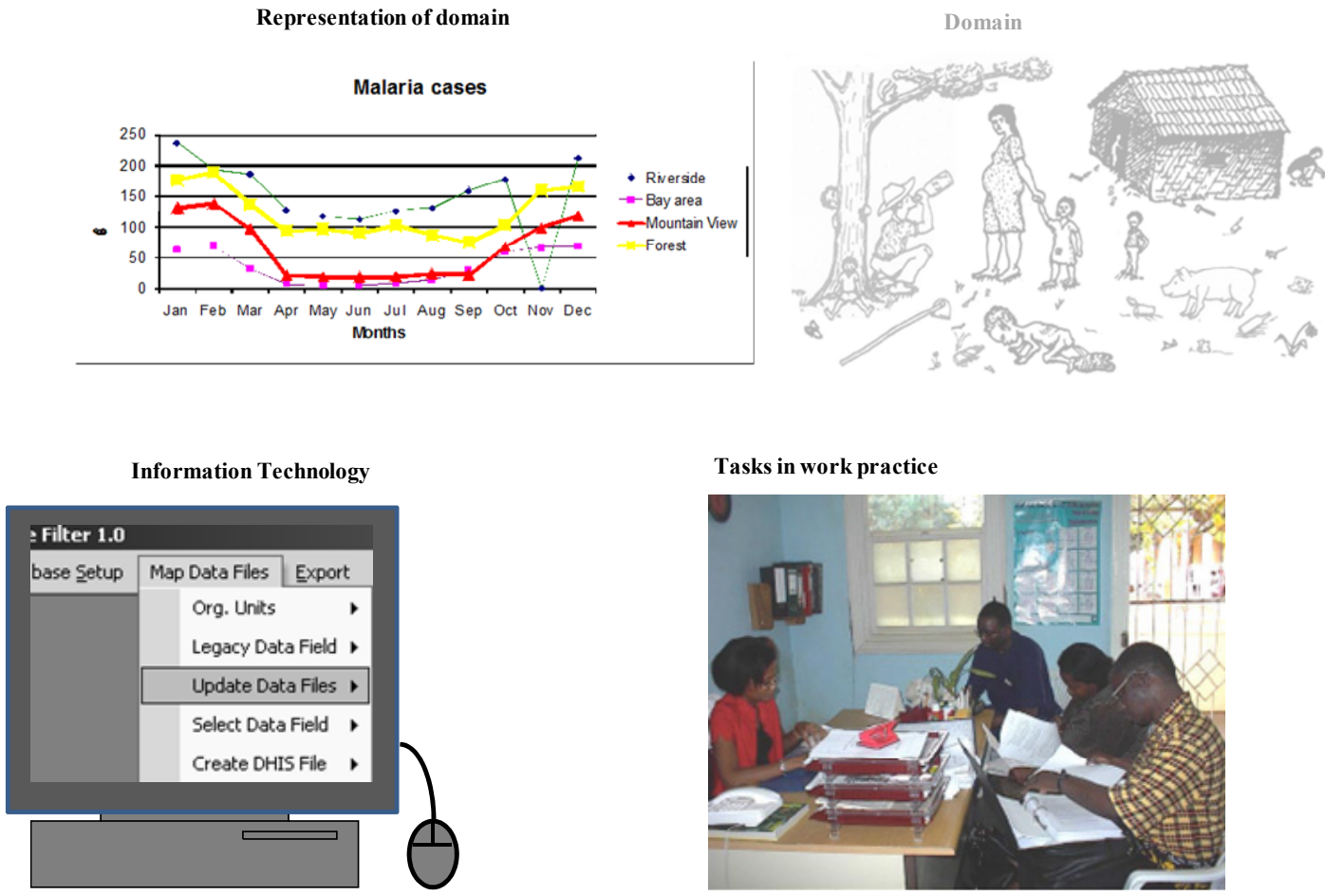

Figure 3. The three competence areas for computer use.

Also the Domain is shown here, in order to illustrate the distinction between Domain and Representation of domain.

In methods for developing information systems, the domain is described in a class model, which is implemented as a data structure, while the tasks are mapped into use cases, providing the functionality of the software. 
Computers have been developed for symbol processing, and the symbols are about a domain, e.g., the numbers in a spreadsheet may represent the purchase of goods. Competent users should therefore also know the relations between the domain and its representation, e.g., in order to interpret it, to reshape it, or to spot misrepresentations. When purchasing goods, users also need to understand the relation between price and the goods being paid for. Computer users therefore need competence in three subject matter areas, as illustrated in Figure 3.

- representation of the domain

- information technology, including its functionality and user interface

- tasks in a work practice

In his study of geographical information systems in India, Puri (2007) identified three aspects of the maps which are going to be shared between GIS personnel and indigenous inhabitants of the mapped area. The first aspect is the contents of the map, or 'the scope of knowledge embedded in the map.' This corresponds to a representation of the domain, as expressed above. Puri's (2007) second aspect is the technology, and the third one is the practices which go into the utilization of the object (p.362).

In a study of another HMIS, Sahay and Molla (2007) identified three competence areas: technical, public health, and implementation and use context. Again, this partitioning corresponds to the one presented above, where the technical area is the technology and the implementation and use context is described as the tasks in a work practice above. Work practice is constituted by health management in the HMIS case. Sahay and Molla (2007) mention public health as the third area, while 'public health and its representations' is a more precise expression in that it also captures the data and their relations to the health of the people.

Understanding the data also requires numerical skills. In this study, 'numeracy' will refer to the ability to calculate percentages and draw graphs. The subject matter areas of competence needed for using HMIS are, thus, management, public health and its representations, numeracy, and computing. Some literature of the learning of these subject matter areas is considered below.

Computer literacy is a scarce competence in many developing countries. Being a machine based on simple principles, one should expect that its teaching would favour the embrained, contextfree, scientific style of competence. However, reports show that mimicking instructors' behaviour displayed by a projector is a favoured style of teaching (Herskin, 2006), thus students get socialised without necessarily understanding the principles behind the operation of the software. Also, such courses tend to favour teaching of computer use that is not related to the learners' work, meaning that they get socialised into the wrong collective. A study of learning of basic principles shows that principles are not learnt unless the teacher explains them explicitly and devotes enough time for practicing (Stamatova \& Kaasbøll, 2007).

A comprehensive study of computer training in an HMIS was carried out in Zanzibar, including general computer literacy and use of the same software as in Malaŵi (Ngoma, Kaasbøll, \& Aanestad, 2008). By using health data and running interactive sessions on data entry and reporting, the middle line managers and staff became socialised into running the system and also contributing to improving data quality. A check on system performance three months after training demonstrated that organisational learning had taken place and had yielded improved performance.

In summary, the literature shows that organisations learn through transformations between explicit and implicit competence. Each of the three subject matter areas of IT user competence may require specific transformations. 


\section{Methodology}

The study took place in the health administration and management in Malawi. The health service workforce of Malawi consists of 15,000 people. According to developing country standards, there should have been twice this number; $64 \%$ of the nursing positions are vacant, and only a minority of the employed staff has the required professional training. A massive hiring is a futile strategy for improving this situation due to the lack of qualified applicants. The health education is of international quality, but computer literacy is scarce. The health service is carried out at clinics to which the patients come. The clinic staff reports quarterly the number of children fully immunised, the new number of HIV positives, the number of nursing hours, and more than 100 other data items on paper forms, which are submitted to the district level, where the data is entered in a computer. The district is staffed with a health manager, immunization, HIV, and several other vertical programme coordinators, and a specifically appointed HMIS coordinator has HMIS as her or his main task in each district. The districts report to the Ministry of Health, where the national HMIS manager works.

Also, almost all the appointed managers and coordinators have patient care duties, and, likewise, all health staff carry out management as part of their job, for example, by organising patient queues and coordinating medication of patients. The HMIS is a system for supporting the management function, so it concerns all staff to a larger or smaller extent.

The software computes health indicators and presents them as graphs showing changes over time. Indicators are presented and discussed in meetings where district managers convene with clinic representatives, and similar meetings take place between the districts and upper level management.

Since the study did not cover individual patient information or medical procedures, the only ethical consideration made was that data collection consumes the health workers' time, which could in many cases have been devoted to patients. This was compensated by a $10 \%$ levy on the research expenses paid to the Malawian Ministry of Health, which granted the permission for data collection.

Aiming at uncovering types of competencies and ways of changing them, a qualitative approach was selected. Within two health districts, 53 interviews were carried out and 13 meetings were observed during August - October, 2006. The two districts were designated by the Ministry of Health because the one district had a good HMIS performance, while the other one performed poorly. The informants were selected by the researchers and covered staff at all levels, with emphasis on staff in various kinds of managerial roles. In addition, two hours of observation was carried out at a master course in public health in March, 2006.

Interviews normally took place in the informants' workplace and took 20 minutes to 2 hours. The interviews conducted were mainly in English but some of the respondents preferred to use the local language Chichewa, which one of the research team members spoke, and she translated when necessary.

Notes were taken, but no voice recording took place due to the informants' unfamiliarity with electronic recording.

\section{Findings}

This section will present empirical findings according to the three subject matter areas and characterise the competencies and related learning. 


\section{Health Management}

The HMIS aims at improving the service by providing managers with a tool to assess performance for subsequent action. One of the programme coordinators gave an example of this:

For example when I get the reports, I check how many EmOCs [Emergency Obstetric Cares] and deaths they had, how many patients were referred from this facility and if they have many cases it shows that they are not able to perform certain functions/services properly so it means they have problems and maybe need training.

The decision taken by the coordinator was based on her embrained public health competence and embodied competence of correspondence between referrals and deaths. Therefore, she considers getting a trainer to share embrained and encoded competence with the health staff, which might manifest itself in organisational learning.

The programme coordinators are responsible for ensuring that the services are organised in a way that meets the patients' needs. One coordinator gave an example of how data was used to modify service delivery in the Family Planning programme:

The reports show how the programme is performing, for example it was noted that there are low figures in Norplant clients and that most women were going to BLM [a private clinic] and we discovered that it was because when women came to get that service at the hospital, they were always told to come another day because no one was available to provide that service. So we decided to commit one day of the week for which someone is made available to provide this service at the hospital.

The cooperation was altered, so organisational learning took place, according to the definition of organisational learning in the literature review. The new competence is of the collective type. The quotation shows that the competence is encoded, and the new practice indicates that it is also embedded in the organisation.

The reports guide the coordinators in identifying problematic areas and these are further investigated during supervision. One coordinator explained that

By looking at the reports, I can see which facilities are having problems in terms of submitting on time and filling the reports (i.e. have gaps) and so I take note of these facilities and when I go for supervision I investigate the reason for this.

The embodied knowledge of being able to spot problems may lead to a discussion with the health staff, opening a space for organisational learning.

In one instance, one coordinator felt that there was nothing he could do to act upon the information as he stated:

I see the graphs showing how we have performed but there is nothing I can do to change the situation because it is the ministry who decides what [amount of drugs] we get.

In this case, the manager could have brought the issue to his superiors, but he ended up doing nothing. Learning took place, but its potential for action did not materialise due to a lack of room for action.

An example from a quarterly meeting between clinic managers and some other clinic staff is presented below. One of the clinic managers (A) presents a nicely, hand drawn graph on immunization and a discussion between him and the manager of another clinic (B) emerges:

A: We only reached $77.6 \%$, which is below the target and worse than the last quarter.

$B:$ Why is it so? 
A: When we had scheduled measles immunisation, only 13 children turned up, and we are not allowed to open the vials when less than 20 come.

B: You can't send the children home; that is not fair. We allow for fewer children.

A: That's not according to the guidelines.

No conclusion is reached, but the dilemma seems obvious to all present, and arguments for both sides were raised. The manager who followed the guidelines perceived that there was no room for action, much similar to the previous case. The other manager, however, did not accept the structure of the encoded guidelines, so this clinic had developed embedded competence through organisational learning. In addition, they had developed the embedded competence that the guidelines could be broken. Thus they learned that their room for manoeuvring could be extended. The explicit discussion that took place might have led to similar or opposite organisational learning in some of the other clinics present in the meeting.

As indicated above, clinic staff manages their own work, they report HMIS data to middle level managers, but this data is not used in the clinics. Some staff expressed a need to learn how they could use collected data in order to understand why data were collected. A health staff member responded why there has been the lack of interest:

$$
\text { ... because we do not understand how we can use it! [the data] }
$$

The health staff seems to possess an embrained competence of the HMIS data and its encoding, but there also seems to be a striking lack of embeddedness of this explicit competence into their own management.

The examples indicate that management competence to a large extent is of the tacit type, and that it has to be embedded in order to be effective.

\section{Representation of the Domain}

For using health information for management, health managers would need to see their performance over time and compared to their neighbours. Time trends and comparisons are best communicated through graphs, so during a meeting, the graph in Figure 4 was presented by a clinic manager. Competence needed for creating this includes calculation of percentages, how time can be represented in graphs, how to determine scales, colour coding, interpretation of percentages larger than and smaller than 100, etc. Arithmetic and visualisation of numbers are competence of the embrained type, which in this case has lead to a successful encoding. There were other examples of more senseless graphs generated by means of a spreadsheet, where for example the percentages of fully immunised, Bacille Calmette-Guérin, penta, polio and measles were occupying one sector each in a pie chart.

When numerators changed place with denominators, for instance dividing the total number of children with those immunised, or dysfunctional graphs were produced, the HMIS officer or others had to turn to their embrained numerical competence and make the mathematical principles become explicit for the health staff or managers. Learning mathematics only through imitating others and never having the principles explained would probably imply that most people would never understand the principles since we are not professional mathematical researchers.

While numeracy concerns the system for representing health information, health managers also need to be able to link numbers with health, which again depends on health competence. For instance, users need to know how vaccines should be stored, how HIV can be prevented, what are the health benefits of closed latrines, etc. Without this scientific knowledge and its embedding in the local community, the health services including the HMIS would be futile. There are time bound regularities in the health of a population group. Tuberculosis incidents are relatively uni- 


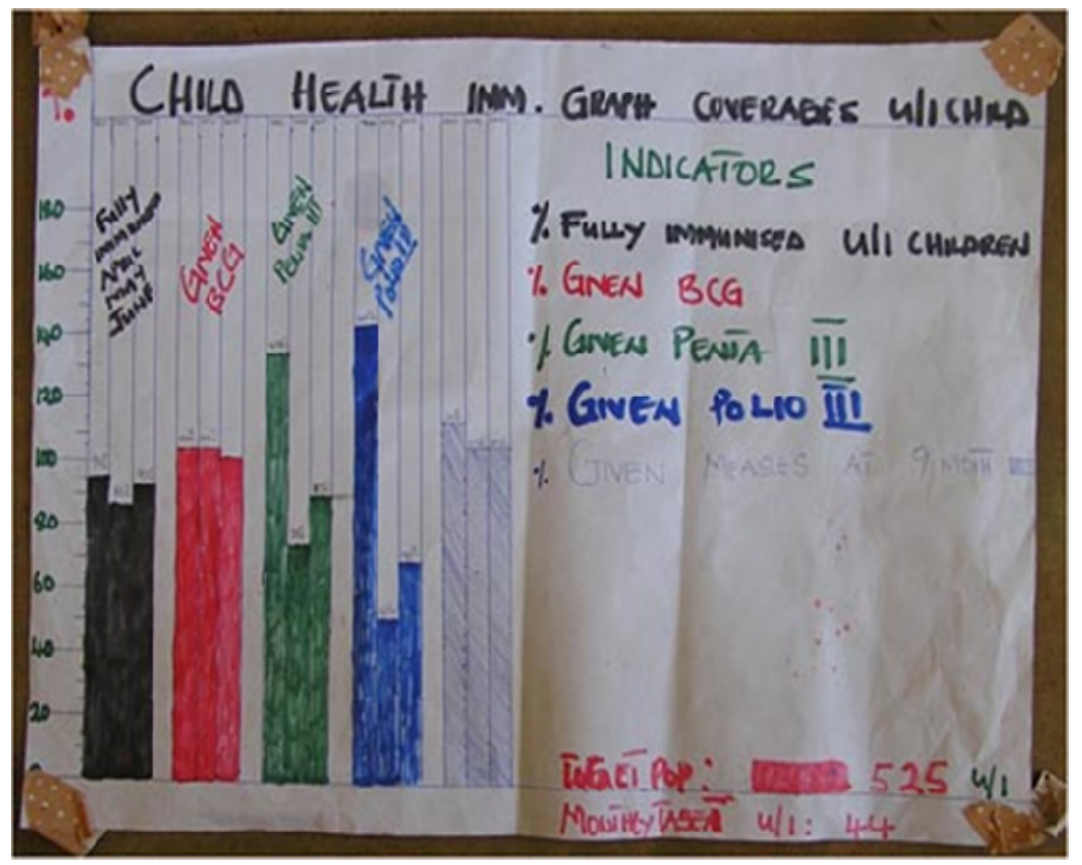

Figure 4. Immunization indicators for three months

formly distributed, malaria has seasonal variations, and cholera have sudden outbreaks. The regularities constitute embrained competence based on science, which a programme manager referred to:

[Facility Name] is the worst performing facility and I know this because when the reports come from this facility, the figures fluctuate a lot so it seems they are just guessing the figures, and they usually report late.

Saying that they report late, the manager indicates that the trouble lies in the reporting, and not in the domain competence of the clinic. Another example also points to the individual competence of managers:

By looking at the coverage rates and dropout rates on the reports, we can compare with the WHO [World Health Organisation] standards and this tells our performance.

The scientific basis of this comparison of encoded performance has been learnt as embrained competence during education. The next two quotations illustrate what a manager does when trying to correct erroneous reports:

At one time, a certain facility reported on the HMIS form that it had zero cases of Malaria and I knew that it could not be true so when I asked the facility they gave me a figure.

By looking at the reports, I can see which facilities are having problems in terms of submitting on time and filling the reports (i.e. have gaps) and so I take note of these facilities and when I go for supervision I investigate the reason for this.

In addition to the embrained competence needed for diagnosing the errors, these managers have also used their embedded social competence for finding reasons for mistakes and achieving a corrected encoding. 


\section{Information Technology}

Clinic staff reported on paper forms, they drew graphs manually as illustrated above, and they infrequently received copies of the computer reports prepared at the district level. The HMIS officer, also called "statistician," was one of the few people in the district who was competent to run the HMIS software. One of the programme coordinators said:

The graphs are used during national level meetings where the data for all districts are reviewed... I ask the statistician to produce graphs for me for the meeting... I give him my programme data to use for making the graphs.

The statistician was regarded competent to do the reporting by means of the software, which requires computer literacy in addition to the domain knowledge and numeracy.

The HMIS officer also knew what the programme reports should look like, so he seems to be sharing the collective competence of knowing who needs what. Even though some of this may be found in encoded guidelines, local adaptations call for development of embedded competence in this area.

\section{Discussion}

The discussion will consider the organisational level as well as the individual level of learning and competence.

Learning at the organisational level was defined in terms of developing a relatively stable change of the potential for cooperation, but this definition said nothing about the process of learning. Nonaka (1994) postulates learning processes of internalising, socialising, externalising, and combination.

The learning processes concerning the HMIS seem to start from two different bases. Learning the arithmetic comprises starting out with concepts and principles of the explicit kinds and internalising and socialising these through working with the real data from the clinics. Without the socialising, no organisational learning of arithmetic will take place. Similar learning processes should happen concerning the domain, its encoding, tools, and computing, but as stated above, learning processes of computing tend to have weaknesses in the initial step of learning explicit concepts and principles. Rather, computer training too often targets only internalising skills.

Learning management starts from practice, where the tacit competence is embedded in the organisation. Based on the embedded competence, general, explicit concepts can be embrained and again internalised, leading to possible individual and also organisational learning. Cooperation patterns may change even if the explicit concepts that were internalised by one manager do not become collective, as long as the internalised change becomes embedded in the organisation.

When planning to improve IT competence in the organisation, Nonaka's (1994) model helps conceptualising the types of learning processes to support. This research has pointed to that the place to start training or support for the learning processes may vary according to the subject matter to be learnt. Learning subject matter grounded in science would need teaching of explicit concepts, while learning subject areas which are mainly of the embodied or embedded type would need to be experienced from practice.

The case points to numeracy, computer literacy, and domain knowledge as three areas necessary for the functioning of HMIS, and all of which originally are of the scientific knowledge type, being explicit and collective, or 'encoded,' according to Lam (2000). She postulates that the embrained (explicit, individual) knowledge is the dominant competence of professional bureaucracies, of which the health sector is a case. 
The managerial competence found is mainly of the embedded type, so it is not in the embrained dominant competence area postulated for professional bureaucracies by (Lam, 2000). The reason may be that Lam's (2000) categorisation concerns the operating core of the organisation, which would be health workers in our case, while this study concerns middle level managers. Since middle managers, regardless of their type of organisation, have to deal with a large variety of tasks, including finance, personnel, and the core business, their competence may be more closely linked to their job than to their business area and type of organisation. Lam's (2000) correspondence theory might therefore need to be modified according to the parts of the organisation considered.

Turning to the individual level, this study points to a revision of the previously suggested competence models for IS users. The 'knowledge domain areas' (Marcolin, et al., 2000) include only the software competence, which is too narrow for covering the subject matter areas found in this study. Sein and colleagues (1998) emphasized that users need to understand both computer systems and its work context, and this is in line with the broader view of user competence shown in this study. Coulson and colleagues (2003) stressed competence for business procedures, again corresponding to the broader view.

This HMIS study confirms that work context is of two kinds -- representation of domain and tasks in the work practice. These categories confirm Puri's (2007) and Sahay and Molla's (2007) categorisation, except that their concept of domain competence should rather be exchanged with competence on the representation of domains.

Coulson and colleagues (2003) observed that many trained users also had to support colleagues, and that conceptual knowledge of the system was helpful for this task. Helping others would require competence at a higher level than using the software for their own, routine tasks. Other tasks that could also require higher level of mastery are solving problems that training has not addressed, learning more, and communicating with software developers. Table 2 summarizes the three areas of competence with mastery levels.

The advanced competence builds on the basic one, but there is no similar cumulative relation between the four advanced competencies. No ranking has therefore been introduced between these.

'Conceptual understanding' is not identified as a competence on its own, but pedagogical research points to its usefulness for the competencies here labelled 'Advanced' (Bransford, 2000).

The Numeracy column is specific for HMIS users, while in other information systems, numeracy may not be an issue. A general model of competence for use of IT can therefore be deducted by removing the Numeracy column from the model.

Work tasks, here managerial, are normally based in practice, while the domain of health is based on science, and it requires numeracy as a third subject matter. Comparing with other kinds of IT, spread sheets would also require both numeracy and the domain of the data. Concerning text processing, language skills and competence for comparing the text with the domain which it is representing are needed for using a particular IT efficiently. 
Table 2. Model of HMIS user competence.

\begin{tabular}{|c|c|c|c|c|c|}
\hline & & \multicolumn{2}{|c|}{ Representation of domain } & \multirow{2}{*}{$\begin{array}{l}\text { Information } \\
\text { Technology }\end{array}$} & \multirow{2}{*}{$\begin{array}{c}\text { Tasks in work } \\
\text { practice }\end{array}$} \\
\hline \multicolumn{2}{|c|}{ Level } & Business domain & Numeracy & & \\
\hline $\begin{array}{l}1 \text { Basic user } \\
\text { competence }\end{array}$ & Skills & $\begin{array}{l}\text { Manipulate the } \\
\text { representations of } \\
\text { the domain }\end{array}$ & $\begin{array}{l}\text { Calculate indi- } \\
\text { cators }\end{array}$ & $\begin{array}{l}\text { Push the right but- } \\
\text { tons }\end{array}$ & $\begin{array}{l}\text { Use appropriate } \\
\text { functionality for } \\
\text { routine tasks }\end{array}$ \\
\hline \multirow[t]{4}{*}{$\begin{array}{l}2 \text { Advanced } \\
\text { competence }\end{array}$} & $\begin{array}{r}\text { Problem } \\
\text { solving }\end{array}$ & $\begin{array}{l}\text { Check and cor- } \\
\text { rect data quality }\end{array}$ & $\begin{array}{l}\text { Check and cor- } \\
\text { rect calcula- } \\
\text { tions }\end{array}$ & $\begin{array}{l}\text { Detect and correct } \\
\text { erroneous use of } \\
\text { the software }\end{array}$ & $\begin{array}{l}\text { Find mistakes in } \\
\text { the match be- } \\
\text { tween tasks and } \\
\text { technology }\end{array}$ \\
\hline & Learning & $\begin{array}{l}\text { Include new data } \\
\text { elements and } \\
\text { ways of manipu- } \\
\text { lation in the skills }\end{array}$ & $\begin{array}{l}\text { Include new } \\
\text { ways of calcu- } \\
\text { lating in the } \\
\text { skills }\end{array}$ & $\begin{array}{l}\text { Include new func- } \\
\text { tionality and user } \\
\text { interface elements } \\
\text { in the skills }\end{array}$ & $\begin{array}{l}\text { Find ways of } \\
\text { using the soft- } \\
\text { ware for better } \\
\text { task support }\end{array}$ \\
\hline & $\begin{array}{r}\text { Help oth- } \\
\text { ers }\end{array}$ & $\begin{array}{l}\text { Support and train } \\
\text { on manipulating } \\
\text { data }\end{array}$ & $\begin{array}{l}\text { Support and } \\
\text { train on calcu- } \\
\text { lating }\end{array}$ & $\begin{array}{l}\text { Support and train } \\
\text { on functionality } \\
\text { and user interface }\end{array}$ & $\begin{array}{l}\text { Support and train } \\
\text { on using the ap- } \\
\text { propriate func- } \\
\text { tionality for us- } \\
\text { ers' tasks }\end{array}$ \\
\hline & $\begin{array}{r}\text { Technical } \\
\text { communi- } \\
\text { cation }\end{array}$ & $\begin{array}{l}\text { Explain the rep- } \\
\text { resentation of the } \\
\text { business domain } \\
\text { to software peo- } \\
\text { ple }\end{array}$ & $\begin{array}{l}\text { Explain the } \\
\text { calculations to } \\
\text { software peo- } \\
\text { ple }\end{array}$ & $\begin{array}{l}\text { Explain poor func- } \\
\text { tionality and user } \\
\text { interface to soft- } \\
\text { ware people }\end{array}$ & $\begin{array}{l}\text { Explain user } \\
\text { tasks to software } \\
\text { people }\end{array}$ \\
\hline
\end{tabular}

\section{Implications and Future Research}

From the practical perspective, the learning for HMIS in an organisation should be supported by training on basic user skills and also on the advanced skills in Table 2 where the technology and the representation of the domain is explained and practiced. The training should also strengthen the skills of using the appropriate functionality in work tasks, which would require that the trainers and training designers have learnt the essentials of users' work tasks prior to planning and conducting the training. One way of doing this can be to include an IT skilled user in design of learning materials, training courses, and IT support.

Since internalisation and socialisation are also necessary for the competence to become institutionalised and spread, users need support at their workplace after completing training courses. A mix of IT specialists and superusers, who are at the advanced level of competence (Table 2), would also be favourable for support, so that all subject matter areas are covered.

From the theoretical perspective, our study suggests that the Nonaka (1994) model of competence development in organisations constitutes a useful basis for understanding the processes of learning use of IS. Further, learning subject matter which is based in science should start from the explicit side of the model, while learning subject matter which is mainly embedded in practice should start with being socialised into the practice. Lam's (2000) model of correspondence between organisation type and competence type may hold for the operating core of organisations, but not necessarily for other parts of the organisation like middle level management. 
Gupta and Bostrom (2006) have developed a generic model for research on IT learning where skills, cognitive, affective and meta-cognitive learning outcomes constitute the dependent variables. It follows from our study that the dependent variables should rather reflect the areas of competence and their levels, as outlined in Table 2.

Coulson and colleagues (2003), Herskin (2006) and Stamatova and Kaasbøll (2007) have pointed to the need for teaching of concepts and principles in computer training, but further research is needed to find better ways of carrying out such training. User training for problem solving and for learning is also an area where we know little more than the fact that metacognitive skills are useful (Phelps et al., 2005), and this area can bring substantial improvements for user learning if research is carried out.

Superuser competence should also address the ability to understand other users' skills and comprehension of information systems and to explain what the users did not understand. Users who act as liaisons with software people need to grasp possible inadequacies in the IT specialists' comprehension of the representation of the domain and the tasks in the work practices, and to explain these matters to the IT specialists. How to foster the advanced competence for helping others and for technical communication is a blank area in IT learning, so this is also an area where research can bring valuable insight.

\section{References}

Braa, J., Monteiro, E., \& Sahay, S. (2004). Networks of action: Sustainable health information system across developing countries. MIS Quarterly, 28(3), 337-362.

Bransford, J. (2000). How people learn: Brain, mind, experience, and school. Washington, D.C.: National Academy Press.

Coulson, T., Shayo, C., Olfman, L., \& Rohm, C. E. T. (2003). ERP training strategies: Conceptual training and the formation of accurate mental models. Proceedings of the 2003 SIGMIS conference on Computer Personnel Research: Freedom in Philadelphia-Leveraging differences and diversity in the IT workforce (pp. 87-97). Philadelphia, Pennsylvania: ACM.

Gupta, S., \& Bostrom, R. P. (2006). End-user training methods: What we know, need to know Proceedings of the 2006 ACM SIGMIS CPR conference on Computer Personnel Research: Forty four years of computer personnel research: achievements, challenges \& the future (pp. 172-182). Claremont, California, USA: ACM.

Herskin, B. (2006). Brugeruddannelse i praksis. Copenhagen: Nyt Teknisk Forlag.

Lai, L. (1997). Strategic competence management. Bergen: Fagbokforlaget Vigmostad \& Bjørke AS.

Lam, A. (2000). Tacit knowledge, organizational learning and societal institutions: An integrated framework. Organization Studies, 21(3), 487-513.

Marcolin, B. L., Compeau, D. R., Munro, M. C., \& Huff, S. L. (2000). Assessing user competence: Conceptualiation and measurement. Information Systems Research, 11(1), 37-60.

Mintzberg, H. (1983). Structure in fives: Designing effective organizations. New Jersey: Prentice-Hall.

Mintzberg, H. (2004). Managers not MBAs: A hard look at the soft practice of managing and management development. California: Berret-Koehler Publishers Inc.

Mukama, F. (2003). A study of health information systems at local levels in Tanzania and Mozambique. Improving the use and management of information in health districts. Unpublished Master, University of Oslo, Oslo.

Ngoma, C., Kaasbøll, J. J., \& Aanestad, M. (2008). From user training to in-service support. In P. Cunningham \& M. Cunningham (Eds.), IST-Africa 2008 Conference Proceedings. Windhoek: International Information Management Corporation Limited. 
Nonaka, I. (1994). A dynamic theory of organisational knowledge creation. Organization Science, 5(1), 1437.

Orlikowski, W. (1992). Learning from Notes: Organizational issues in groupware implementation. The Information Society, 30(1), 237-250.

Phelps, R., Hase, S., \& Ellis, A. (2005). Competency, capability, complexity and computers: Exploring a new model for conceptualising end-user computer education. British Journal of Educational Technology, 36(1), 67-84.

Puri, S. (2007). Integrating scientific with indigenous knowledge: Constructing knowledge alliances for land management in India. MIS Quarterly, 31(2), 25.

Sahay, S., \& Molla, S. (2007). Towards integrated capacity building efforts for e-health: The case of HIS in developing countries. Paper presented at the 9th International Conference on Social Implications of Computers in Developing Countries.

Sein, M. K., Bostrom, R. P., \& Olfman, L. (1998). Conceptualizing IT training for the workforce of the future. $\operatorname{SIGCPR,30(1),223-241.}$

Skorve, E. (2007). Strategisk EVUlusjon. Fra individuell lcering til organisatorisk endringskompetanse. Fra lceringsteori til undervisningspraksis. University of Oslo, Oslo.

Stamatova, E., \& Kaasbøll, J. J. (2007). Users' learning of principles of computer operations. Issues in Informing Science and Information Technology, 4, 291-306. Retrieved from http://proceedings.informingscience.org/InSITE2007/IISITv4p291-306Stam300.pdf

Williamson, L. (2001). Evaluation of an in-house trading course for district level health workers in the Cape Metropole region. Unpublished Master, University of Western Cape, Cape Town.

\section{Biographies}

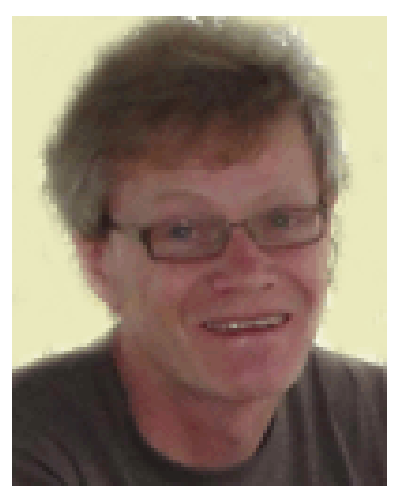

Jens Kaasbøll is a professor in information systems at the Department of Informatice, University of Oslo. He has previously researched the learning and teaching of computer programming. For the last 10 years, he has carried out research in health information systems in developing countries, and user learning, training and support have been major parts of strengthening these systems. The activities also include building academic competence in universities in Ethiopia, Malawii, Mozambique and Tanzania.

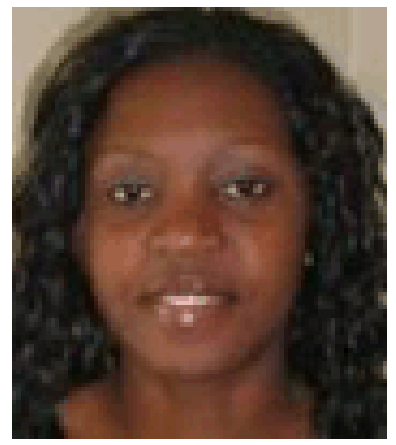

Marlen Stacey Chawani is a PhD Candidate in the Department of Informatics at the University of Oslo, Norway. Her research interests are related to design and implementation of Health Information Systems in Developing countries mainly in rural settings. She holds an MSc in Information Systems from the University of Oslo and a BSc in Computer Science from the University of Malawi. 

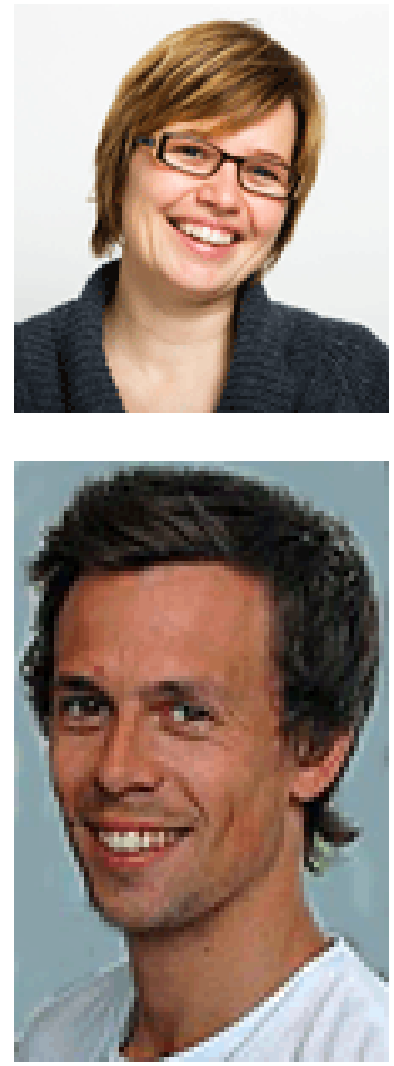

Gro Alice Hamre is a $\mathrm{PhD}$ candidate at the Department of Computer and Information Science at the Norwegian University of Science and Technology. She studies development and use of information systems in organizations, with a special focus on collaboration across organisations. She holds a master in information systems from the University of Oslo where she studied the use of the national Health Management Information System in Malawii.

Jon Sandvand has a Master's degree in informaticts from the University of Oslo. He wrote a Master thesis on organisational startegies for improving health information at district level in Malawi. He is currently employed at Inmeta Consulting where he is working as a software delveloper in the Banking and Insurance department. 